\title{
KAJIAN KRITIS TEORI HUKUM PROGRESIF \\ TERHADAP STATUS ANAK DI LUAR NIKAH \\ DALAM PUTUSAN MAHKAMAH KONSTITUSI No.46/PUU-VIII/2010
}

\author{
Saifullah \\ UIN Maulana Malik Ibrahim Malang \\ Jl. Gajayana No.50 Malang 65144 \\ Email :saifullahdebab@yahoo.co.id
}

\begin{abstract}
Abstrak
Kajian kritis Teori Hukum Progresif yang digagas oleh Satjipto Rahardjo telah diterjemahkan dalam putusan Mahkamah Konstitusi No.46/PUU-VII/2010 tentang status hukum anak luar nikah sebagai berikut : (a) putusan yang menempatkan hukum untuk manusia bukan manusia untuk hukum ; (b) putusan yang merespon keinginan pencari keadilan dan memberikan nilai kesejahteraan dan kebahagiaan utamanya ibu yang melahirkan dan keluarganya dengan memberikan perlindungan hak-hak keperdataan bagi anak luar nikah ; (c) putusan yang mengakomodir keinginan publik dengan melakukan rule breaking oleh hakim dalam mengaktualisasikan hukum dalam ruang dan waktu yang tepat dengan melakukan pemaknaan yang kreatif terhadap peraturan yang ada agar hukum juga mengatur dan menjamin hak-hak keperdatan anak di luar perkawinan dari kedua orangtuanya ; (d) putusan yang mengejawantahkan nilai kecerdasan moral dan spiritual dengan kandungan nilai keadilan substantif ; (e) putusan yang mengganti dan menerobos paradigma bekerjanya hukum sesuai peraturan menuju ke paradigma perilaku manusia.
\end{abstract}

Kata kunci: hukum progresif, Satjipto Rahardjo, anak di luar nikah, putusan Mahkamah Konstitusi, rule breaking

\begin{abstract}
Critical Reviews of Progressive Legal Theory initiated by Satjipto Rahardjo has been translated in the decision of Constitutional Court No : 46/PUU-VII/2010 about the legal status of illegitimate children out of wedlock as follows : (a) a decision that puts the law for human, not human for the law ; (b) responding to the decision that in the search of justice and provide welfare and happiness of its main values that gave birth mothers and their familes with provide protection for the civil rights of illegitimate children out of wedlock ; (c) the decision to accommodate the public desire to perform rule breaking by the judge in the legal actualize in space and time by performing a creative interpretation of existing regulations that regulate the law also guarantees the right and civil rights of a natural child of his parents ; (d) the decision that embody moral intelligence and spiritual values with the substantive content of justice ; (e) decision to break through the workings of the legal paradigm in accordance with the human behaviour paradigm.
\end{abstract}

Keywords: progresive law, Sactipto Rahardja, ex-nuptial child, Constitution Court decision, rule breaking. 


\section{A. Pendahuluan}

Hasil Rapat Musyawarah Hakim yang dihadiri oleh sembilan orang Hakim Mahkamah Konstitusi dan dibacakan terbuka untuk umum pada tanggal 17 Februari 2012 dalam Sidang Pleno Mahkamah Konstitusi dengan registrasi No : 46/PUU-VII/2010 telah memberikan pengaruh yang signifkan tidak saja menjadi perdebatan panjang di kalangan akademisi dan praktisi tetapi juga organisasi sosial dan keagamaan.

Dalil yang disampaikan pemohon adalah hak-hak konstitusional mereka yang dijamin oleh Negara melalui pasal 28B ayat (1) dan pasal 28B ayat (2) UUD 1945 telah terhalangi berdasarkan pasal 51 ayat (1) Undang-Undang Mahkamah Konstitusi, ${ }^{1}$ dengan adanya pasal 2 ayat (2) dan pasal 43 ayat (1) UU Perkawinan. Menurut pemohon perkawinan mereka sah menurut rukun nikah Islam. Akan tetapi sahnya perkawinan tersebut terhalangi oleh pasal 2 ayat (2) yang mengharuskan sebuah perkawinan dicatat menurut peraturan perundang-undangan yang berlaku. Di samping perlakuan diskriminatif pada hak status hukum anak yang dilahirkan karena cara pernikahan yang berbeda mengakibatkan status anak di muka hukum menjadi tidak jelas dan sah. Pemohon menganggap bahwa hal yang berbeda telah diperlakukan kepada anak pemohon, yang mana dihasilkan dari perkawinan yang sah sesuai dengan rukun nikah dan norma agama tetapi justru dianggap tidak sah oleh UU Perkawinan. $^{2}$ Pemohon juga merasakan bahwa anak yang dilahirkan telah mendapatkan perlakuan diskriminatif yaitu dengan dihilangkan asal-usul kelahirannya dengan cara hanya mencantumkan nama Ibunya dalam Akta Kelahirannya. Negara juga menghilangkan hak anak untuk kelangsungan hidup, tumbuh dan berkembang karena dengan hanya mempunyai hubungan keperdataan dengan ibunya mengakibatkan suami tidak mempunyai kewajiban hukum untuk memelihara, mengasuh serta membiayai anak yang telah dilahirkan. Dikatakan pula bahwa diskriminasi tersebut telah memberikan beban psikis terhadap anak dikarenakan tidak adanya pengakuan dari bapaknya atas kehadirannya di dunia, yang menimbulkan rasa kecemasan, ketakutan dan ketidaknyamanan anak dalam pergaulan di masyarakat. Hak konstitusional ini terhalangi oleh Pasal 43 ayat (1) UUD $1945 .^{3}$

Keterangan dari Pemerintah terkait uji materiil tersebut menjelaskan bahwa pencatatan perkawinan sebagaimana dimaksud dalam pasal 2 ayat (2) UU Perkawinan sesungguhnya bertujuan untuk: tertib administrasi perkawinan; memberikan kepastian dan perlindungan terhadap status hukum suami, istri maupun anak; dan memberikan jaminan dan perlindungan terhadap hak-hak tertentu yang timbul karena perkawinan seperti hak waris, hak untuk memperoleh akta kelahiran, dan lain-lain. ${ }^{4}$ Menurut Pemerintah pencatatan bukanlah untuk membatasi hak asasi warga Negara dalam melangsungkan perkawinan, melainkan sebaliknya yaitu untuk melindungi warga Negara dalam membangun keluarga dan melanjutkan keturunan, serta memberikan kepastian hukum terhadap hak suami, istri dan anak-anaknya.

Pemerintah juga menjelaskan perihal UU Perkawinan menganut asas monogami, akan tetapi tidak menutup kemungkinan seorang suami untuk beristri lebih dari satu. Poligami dapat dilakukan dengan memenuhi persyaratan yang ditentukan oleh UU Perkawinan khususnya yang ditentukan dalam pasal 3 ayat (2), Pasal 4 dan Pasal 5 serta Peraturan Pemerintah Nomor 9 Tahun 1975. ${ }^{5}$ Perkawinan poligami yang tidak memenuhi persyaratan sebagaimana diperintahkan oleh undang-undang akan mengakibatkan perkawinan tersebut tidak dapat dicatatatkan di Kantor Urusan Agama atau Kantor Catatan Sipil dengan 
segala akibat hukumnya. Persyaratan dan prosedur perkawinan poligami ini berlaku untuk setiap warga Negara Indonesia dan tidak memberikan perlakuan diskriminatif terhadap orang atau golongan tertentu termasuk terhadap para Pemohon. ${ }^{6}$

Pemerintah menanggapi dengan menyatakan bahwa Pasal 43 ayat (1) UU Perkawinan tersebut sebenarnya bertujuan untuk memberikan perlindungan dan kepastian hukum terhadap anak dengan ibu serta keluarga ibunya, karena suatu perkawinan yang tidak dicatat dapat diartikan bahwa peristiwa perkawianan tersebut tidak ada. Ketentuan ini merupakan konsekuensi logis dari adanya persyaratan pencatatan perkawinan yang sah. Adalah tidak logis apabila undang-undang memastikan hubungan hukum seorang anak yang lahir dari seorang perempuan memiliki hubungan hukum sebagai seorang anak dengan seorang laki-laki yang tidak terikat dalam perkawinan yang sah. ${ }^{7}$

$$
\text { Keterangan dari DPR RI }
$$

memandang bahwa pencatatan perkawinan adalah suatu kebutuhan formal untuk legalitas atas suatu peristiwa yang dapat mengakibatkan suatu konsekuensi yuridis, dan bahwa tujuan pencatatan perkawinan yaitu sebagai berikut: untuk tertib administrasi perkawinan; jaminan memperoleh hakhak tertentu (memperoleh akte kelahiran, membuat Kartu Tanda Penduduk, membuat Kartu Keluarga, dan lain-lain); memberikan perlindungan terhadap status perkawinan; memberikan kepastian terhadap status hukum suami, istri maupun anak; memberikan perlindungan terhadap hak-hak sipil yang diakibatkan oleh adanya perkawinan. ${ }^{8}$ Pencatatan perkawinan dalam bentuk akta perkawinan menjadi penting untuk memberikan jaminan kepastian hukum dan perlindungan hukum untuk setiap perkawinan, sehingga dalil yang menyatakan Pasal 2 ayat (2) UU Perkawinan telah menimbulkan ketidakpastian hukum adalah anggapan yang keliru dan tidak berdasar. Kemudian dalam keterangan tersebut DPR RI merujuk kepada Putusan Mahkamah Konstitusi Perkara Nomor: 12/PUU$\mathrm{V} / 2007$ dalam pertimbangan hukum halaman 97-98 menyebutkan: "bahwa pasal-pasal yang tercantum dalam UU Perkawinan yang memuat alasan, syarat, dan prosedur poligami sesungguhnya semata-mata sebagai upaya untuk menjamin dapat terpenuhinya hak-hak istri dan calon istri yang menjadi kewajiban suami yang akan berpoligami dalam rangka mewujudkan tujuan perkawinan. Oleh karena itu penjabaran persyaratan poligami tidak bertentangan dengan Pasal 28B ayat (1) UUD Negara Republik Indonesia Tahun 1945."

Terdapat 2 (dua) hal pokok yang penting pertimbangan hukum yang dinyatakan oleh Majelis Hakim yaitu : (1) Bahwa pokok permasalahan hukum mengenai pencatatan perkawinan menurut peraturan perundang-undangan adalah mengenai makna hukum (legal meaning) pencatatan perkawinan. Dengan berdasarkan pada Penjelasan UU Perkawinan, ${ }^{9}$ mengenai kewajiban pencatatan perkawinan, Majelis menyatakan bahwa $^{10}$ pencatatan perkawinan bukanlah merupakan faktor yang menentukan sahnya perkawinan dan pencatatan merupakan kewajiban administratif yang diwajibkan berdasarkan peraturan perundangundangan. Pentingnya pencatatan perkawinan dapat dipandang dari 2 (dua) perspektif. Pertama, dari perspektif negara, pencatatan yang dimaksud diwajibkan dalam rangka fungsi negara memberikan jaminan perlindungan, pemajuan, penegakan dan pemenuhan hak asasi manusia yang bersangkutan yang merupakan tanggung jawab negara dan harus dilakukan sesuai dengan prinsip negara hukum yang demokratis yang diatur secara dituangkan dalam peraturan perundang-undangan (vide Pasal 28 I ayat (4) dan ayat (5) UUD'45). 
Sehingga persyaratan pencatatan tidak dapat dipandang sebagai pembatas, namun lebih kepada untuk menjamin pengakuan serta penghormatan atas hak dan kebebasan orang lain. ${ }^{11}$ Kedua, pencatatan secara administratif dimaksudkan sebagai perbuatan hukum penting yang berimplikasi terjadinya akibat hukum yang sangat luas. Perbuatan hukum yang mana dikemudian hari dapat dibuktikan dengan alat bukti yang sempurna yaitu akta otentik, sehingga hak-hak yang timbul sebagai akibat hukum perkawinan dapat terlindungi dan terlayani dengan baik oleh negara. Majelis Hakim memberikan contoh misalnya untuk pembuktian asal-usul anak. Apabila asal usul anak tidak dapat dibuktikan dengan akta otentik, maka mengenai hal itu akan ditetapkan dengan putusan pengadilan yang berwenang. Pembuktian yang demikian pasti tidak efektif dan efisien karena memakan waktu, uang, tenaga, dan pikiran yang lebih banyak dibandingkan dengan adanya akta otentik sebagai buktinya. ${ }^{12}$

Pertimbangan hukum yang kedua adalah, bahwa pokok permasalahan hukum mengenai anak yang dilahirkan diluar perkawinan adalah mengenai makna hukum (legal meaning) frasa "yang dilahirkan di luar perkawinan". Majelis mengkaji masalah ini dengan melihat kepada tentang sahnya anak. Secara alamiah, tidaklah mungkin seorang perempuan hamil tanpa terjadinya pertemuan antara ovum dan spermatozoa baik melalui hubungan seksual (coitus) maupun melalui cara lain berdasarkan perkembangan teknologi yang menyebabkan terjadinya pembuahan. ${ }^{13}$ Oleh karena itu, tidaklah tepat dan adil apabila anak diputuskan hanya mempunyai hubungan keperdataan dengan ibunya, jika hanya dikarenakan anak itu lahir di luar pernikahan yang sah. Tidak adil pula seorang laki-laki bebas dari tanggung jawabnya sebagai seorang bapak dan bersamaan dengan itu hukum juga ikut meniadakan hubungan hukum anak dengan laki-laki tersebut sebagai bapaknya. Apalagi, dewasa ini berdasarkan kemajuan teknologi memungkinkan pembuktian seorang anak apakah ia merupakan anak dari laki-laki tertentu. Dengan demikian, hubungan anak dengan seorang laki-laki sebagai bapaknya tidak semata-mata karena adanya ikatan perkawinan, akan tetapi dapat juga berdasarkan pembuktian melalui teknologi.

Menurut Majelis, terlepas dari soal administrasi perkawinannya, anak yang dilahirkan harus mendapat perlindungan hukum. Karena anak walaupun dilahirkan diluar perkawinan adalah tidak berdosa. Hukum harus memberikan perlindungan karena seringkali anakanak itu mendapat perlakuanyang tidak adil dan stigma di tengah-tengah masyarakat. Perlindungan diberikan kepada status seorang anak yang dilahirkan dan hak-hak yang ada padanya, termasuk terhadap anak yang lahir meskipun keabsahan perkawinannya masih dipersengketakan. ${ }^{14}$

Berdasarkan pertimbangan yang telah diajukan tersebut, maka dalil Pemohon sepanjang menyangkut Pasal 2 ayat (2) UU Perkawinan oleh Majelis Hakim dinyatakan tidak beralasan menurut hukum. Sedangkan Pasal 43 ayat (1) UU Perkawinan adalah bertentangan dengan UUD 1945 secara bersyarat (conditionally unconstitutional). Dikatakan inkonstitusional sepanjang ayat tersebut dimaknai menghilangkan hubungan perdata dengan laki-laki yang dapat dibuktikan berdasarkan ilmu pengetahuan dan teknologi dan/atau alat bukti lain menurut hukum mempunyai hubungan darah sebagai ayahnya. ${ }^{15}$

Dalam amar putusannya Majelis Hakim juga memutuskan : Pasal 43 ayat (1) UU Perkawinan yang menyatakan, "Anak yang dilahirkan di luar perkawinan hanya mempunyai hubungan perdata dengan ibunya dan keluarga ibunya", bertentangan dengan UUD 1945 
sepanjang dimaknai menghilangkan hubungan perdata dengan laki-laki yang dapat dibuktikan berdasarkan ilmu pengetahuan dan teknologi dan/atau alat bukti lain menurut hukum ternyata mempunyai hubungan darah sebagai ayahnya, sehingga ayat tersebut harus dibaca, "Anak yang dilahirkan di luar perkawinan mempunyai hubungan perdata dengan ibunya serta dengan lakilaki sebagai ayahnya yang dapat dibuktikan berdasarkan ilmu pengetahuan dan teknologi dan/atau alat bukti lain menurut hukum mempunyai hubungan darah termasuk hubungan perdata dengan keluarga ayahnya"

Terhadap putusan tersebut, Hakim Konstitusi yang lain yaitu Maria Farida Indrati memiliki alasan yang berbeda (concurring opinion). ${ }^{16}$ Menurutnya, kebebasan norma agama dan norma hukum dalam suatu peraturan memiliki potensi untuk saling melemahkan dan bertentangan satu sama lain, sebagaimana terjadi pada Pasal 2 ayat (1) UU Perkawinan yang menggunakan norma agama dan Pasal 2 ayat (2) UU Perkawinan yang menitikberatkan pada norma hukum. Keberadaan Pasal 2 ayat (2) UU Perkawinan juga telah menimbulkan ambiguitas bagi pemaknaan Pasal 2 ayat (1) UU Perkawinan dikarenakan dalam pencatatan yang dimaksud Pasal 2 ayat (1) UU Perkawinan, tidak ditegaskan apakah pencatatan itu hanya bersifat administratif. Dengan concurring opinionnya, Hakim Konstitusi Maria juga menjelaskan potensi kerugian yang mungkin timbul sebagai akibat dari tidak adanya pencatatan perkawinan yang didasarkan pada UU Perkawinan. Perlindungan dari Negara kepada wanita sebagai isteri atas kerugian yang dialami selama perkawinan, hanya dapat diberikan oleh Negara jika perkawinan dilakukan secara sadar menurut UU Perkawinan. Salah satunya yaitu dengan melakukan pencatatan perkawinan. Beberapa contoh potensi kerugian yang mungkin diderita isteri adalah mengenai status perkawinan, harta gono gini, waris, dan hak hak lain yang timbul dari sebuah perkawinan.Potensi kerugian terhadap anak yang lahir dari perkawinan tidak tercatat juga ada baik secara materiil maupun secara sosio psikologis. Tidak diakuinya hubungan anak dengan ayah biologisnya tentu akan mengakibatkan tidak dapat dituntutnya kewajiban lakilaki sebagai ayah untuk membiayai kehidupan anak dan hak-hak keperdataan lainnya. Selain itu, keberadaan anak dalam keluarga yang tidak memiliki pengakuan dari ayah biologisnya dapat memberikan stigma negatif, misalnya sebagai anak haram. ${ }^{17}$

Putusan Hakim Mahkamah konstitusi tersebut menimbulkan banyak tanggapan baik yang pro maupun yang kontra. ${ }^{18}$ Termasuk di dalamnya dunia pendidikan hukum yang secara akademis tentu saja menimbulkan beragam pemikiran konseptual maupun dilakukannya berbagai penelitian. Putusan MK tersebut sangatlah signifikan jika dikaji secara kritis dari pendekatan sosiologi hukum khususnya Teori Hukum Progresif yang digagas oleh Satjipto Rahardjo.

\section{B. Konsep Dasar Teori Hukum Progresif}

Teori Hukum Progresif selanjutnya disingkat THP) yang digagas oleh Satjipto Rahardjo dimulai dari kegelisahan intelektual beliau yang melihat kondisi penegakan hukum di tanah air yang berlarut-larut tanpa ada penyelesaian hukum yang tuntas dengan memegang prinsip keadilan yang menjadi cikal bakal kepastian hukum. Hal ini juga disumbang oleh proses pendidikan hukum di tanah air yang menyebabkan belum beranjak dari paradigma positivistik-legalistik sehingga mempengaruhi sebagian besar kaum cendikiawan, intelektual dan ilmuwan hukum. Kondisi ini terjadi ditenggarai karena aparatur penegak hukum belum 
tercerahkan yang sebagian besar mereka masih menggunakan optic positivistic dalam memeriksa dan memutuskan perkara hukum. Hal ini juga disumbang oleh proses pendidikan hukum di tanah air yang menghasilkan alumni dengan menggunakan paradigma positivistiklegalistik tersebut. ${ }^{19}$

Gagasan hukum dan ilmu hukum progresif pertama tama didasari oleh keprihatinan terhadap kontribusi rendah ilmu hukum di Indonesia dalam untuk turut mencerahkan bangsa ini untuk keluar dari krisis, termasuk di bidang hukum. Ilmu hukum progresif adalah tipe ilmu yang selalu gelisah melakukan pencarian dan pembebasan. ${ }^{20}$ Untuk memahami Teori Hukum Progresif Satjipto Rahardjo bukanlah semudah namanya, karena memerlukan bacaan yang lebih dalam mengenai latar belakang pemikiran munculnya teori tersebut. Teori Hukum Progresif Satjipto Rahardjo berawal dari kegelisahannya bahwa setelah 60 tahun usia Negara hukum, terbukti tidak kunjung mewujud suatu kehidupan hukum yang lebih baik. Bertolak dari kenyataann pahit mengenai kehidupan dan peranan hukum yang ia konstatir maka muncullah keinginan untuk kembali kepada fundamental hukum di negeri ini. Bahkan almarhum memikirkan kemungkinan adanya kekeliruan atau kekurangtetapan dalam memahami (understanding) fundamental hukum tersebut sehingga almarhum menegaskan adanya perkembangan hukum tidak dapat diarahkan kepada yang benar. ${ }^{21}$

Buah pemikiran Satjipto Rahardjo yang dituangkan terus bergulir sepanjang perjalanan kehidupan beliau seiring dengan muncul dan tenggelamnya kasuskasus di tanah air. ${ }^{22}$ Upaya beliau untuk mencerahkan pemikiran generasi muda khususnya yang berkecimpung di dunia akademisi dititipkan khusus agar pola pikir dalam memahami pendekatan sosiologis utamanya dalam mengkaji kasus hukum. Pencerahan tersebut juga dilakukan di kalangan penegak hukum yang sehari-hari bekerja di dunia hukum agar mereka mempunyai pandangan yang menyeluruh (the hole complexs) dalam memeriksa sampai memutuskan perkara hukum.

Satjipto Rahardjo tidak secara baku menetapkan definisi dan ruang lingkup teori hukum progresif tersebut. Upaya ini sesungguhnya secara filosofis maupun sosiologis, para akademisi diberi kebebasan untuk merumuskan pemikiran masing-masing di sepanjang sejarah pergulatan pemikiran hukum. Sejak digulirkannya gagasan Teori Hukum Progresif di tahun 2002 dan dipublikasikan secara utuh dalam tulisantulisan beliau dengan penyebutan Hukum Progresif, walaupun menurut pandangan beliau bahwa "roh" tentang Hukum Progresif sebenarnya tak dapat dipungkiri bahwa jauh sebelumnya banyak tulisan beliau sebagai refleksi kritis telah dilahirkan sebagai embrio ide Hukum Progresif.

Sepanjang perjalanan wacana Teori Hukum Progresif muncullah beberapa tipologi yang merangkum berbagai pemikiran baik itu hasil penelitian maupun olah pikir sosiolog hukum yang penulis uraikan di bawah ini :

Sidharta melakukan telaah atas gagasan dan pemikiran THP tersebut dari berbagai sumber data primer maupun sekunder dan menyimpulkan terdapat postulat-postulat yang menjadi kata kunci pada pemikiran hukum progresif yaitu: ${ }^{23}$

1. Hukum progresif itu untuk manusia, bukan manusia untuk hukum. Pada hakekatnya setiap manusia itu baik, sehingga sifat ini layak menjadi modal dalam membangun kehidupan berhukumnya. Hukum bukan raja (segalanya), tetapi sekedar alat bagi manusia untuk memberi rahmat kepada dunia dan kemanusiaan. Hukum tidak ada untuk dirinya sendiri melainkan untuk sesuatu yang lebih luas dan 
lebih besar. Maka, setiap ada masalah dalam dan dengan hukum, hukumlah yang ditinjau serta diperbaiki, bukan manusia yang dipaksa-paksa untuk dimasukkan ke dalam skema hukum.

2. Hukum progresif itu harus pro rakyat dan pro keadilan. Hukum itu harus berpihak kepada rakyat. Keadilan harus didudukkan di atas peraturan. Para penegak hukum harus berani menerobos kekakuan teks peraturan (diistilahkan mobilisasi hukum).

3. Hukum progresif bertujuan mengantarkan manusia kepada kesejahteraan dan kebahagiaan. Hal ini juga sejalan dengan cara pandang orang Timur yang memberikan pengutamaan pada kebahagiaan.

4. Hukum progresif selalu dalam proses menjadi. Hukum bukan institusi yang final, melainkan ditentukan oleh kemampuannya mengabdi kepada manusia.

5. Hukum progresif menekankan hidup baik sebagai dasar hukum yang baik. Dasar hukum terletak pada perilaku bangsanya sendiri karena perilaku bangsa itulah yang mentukan kualitas berhukum bangsa tersebut.

6. Hukum progresif memiliki tipe responsif. Dalam tipe responsive, hukum akan selalu dikaitkan pada tujuan-tujuan di luar narasi tekstual hukum itu sendiri. Tipe responsive menolak otonomi hukum yang bersifat final dan tidak dapat digugat.

7. Hukum progresif mendorong peran publik. Mengingat hukum memiliki kemampuan yang terbatas, maka mempercayakan segala sesuatu kepada kekuatan hukum adalah sikap yang tidak realistis dan keliru. Untuk itu hukum progresif sepakat memobilisasi kekuatan otonom masyarakat (mendorong peran publik).

8. Hukum progresif membangun Negara hukum yang berhati nurani. Dalam bernegara hukum, yang utama adalah kultur. Kultur yang dimaksud adalah kultur pembahagiaan rakyat.

9. Hukum progresif dijalankan dengan kecerdasan spiritual. Kecerdasan spiritual tidak ingin dibatasi patokan, juga tidak hanya bersifat kontekstual, tetapi ingin keluar dari situasi yang ada dalam usaha mencari kebenaran makna atau nilai yang lebih dalam.

10. Hukum progresif itu merobohkan, mengganti dan membebaskan. Hukum progresif menolak sikap status quo dan submisif. Sikap status quo menyebabkan kita tidak berani melakukan perubahan dan menganggap doktrin sebagai sesuatu yang mutlak untuk dilaksanakan. Sikap demikian hanya merujuk kepada maksim 'rakyat untuk hukum'.

Yudi Kristiana lebih mengkristalkan lagi pola pikirnya dalam bentuk tabel di bawah ini dengan melakukan identifikasi secara terperinci sebagai berikut:

\begin{tabular}{|c|c|}
\hline \multicolumn{2}{|c|}{ Identifikasi Hukum Progresif ${ }^{24}$} \\
\hline Identifikasi & Hukum Progresif \\
\hline Asumsi & $\begin{array}{l}\text { 1. Hukum untuk manusia } \\
\text { bukan sebaliknya ; } \\
\text { 2. Hukum bukan merupakan } \\
\text { institusi yang mutlak dan } \\
\text { final tetapi selalu dalam } \\
\text { proses untuk menjadi (law } \\
\text { as a process, law in the } \\
\text { making) }\end{array}$ \\
\hline Tujuan & $\begin{array}{l}\text { Kesejahteraan dan kebahagiaan } \\
\text { manusia }\end{array}$ \\
\hline Spirit & $\begin{array}{l}\text { 1. Pembebasan terhadap tipe, } \\
\text { cara berfikir, asas dan teori } \\
\text { yang selama ini dipakai } \\
\text { (mendominasi) } \\
\text { 2. } \begin{array}{l}\text { Pembebasan terhadap kultur } \\
\text { penegakan hukum }\end{array}\end{array}$ \\
\hline
\end{tabular}




\begin{tabular}{|c|c|c|}
\hline & & $\begin{array}{l}\text { (administration of justice ) } \\
\text { yang selama ini berkuasa } \\
\text { dan dirasa menghambat } \\
\text { hukum } \\
\text { menyelesaikan persoalan. }\end{array}$ \\
\hline Progresivitas & & 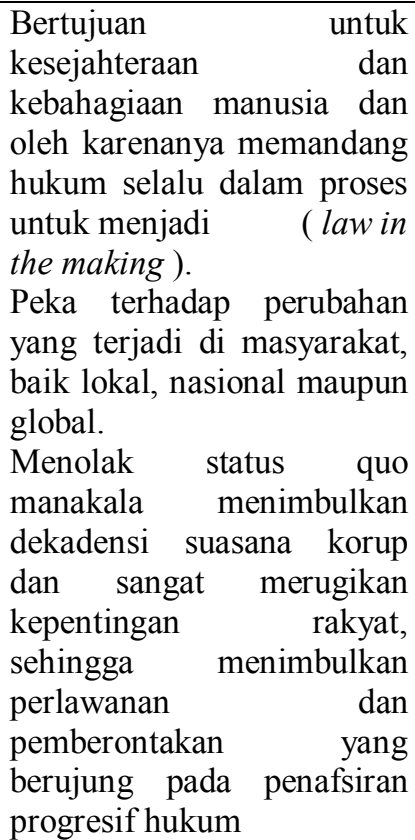 \\
\hline Karakter & & $\begin{array}{l}\text { Kajian hukum progresif } \\
\text { berusaha mengalihkan titik } \\
\text { berat kajian hukum yang } \\
\text { semula menggunakan optik } \\
\text { hukum menuju ke perilaku; } \\
\text { Hukum progresif secara } \\
\text { sadar menempatkan } \\
\text { kehadirannya dalam } \\
\text { hubungan erat dengan } \\
\text { manusia dan masyarakat, } \\
\text { meminjam istilah Nonet dan } \\
\text { Selznick bertipe responsive; } \\
\text { Hukum progresif berbagi } \\
\text { faham dengan legal realism } \\
\text { karena hukum tidak } \\
\text { dipandang dari kacamata } \\
\text { hukum itu sendiri, } \\
\text { melainkan dilihat dan } \\
\text { dinilai dari tujuan social } \\
\text { yang ingin dicapai dan } \\
\text { akibat yang timbul dari } \\
\text { bekerjanya hukum; } \\
\text { Hukum progresif memiliki } \\
\text { kedekatan dengan } \\
\text { sociological jurisprudence } \\
\text { dari Roscoe Pound yang } \\
\text { mengkaji hukum tidak } \\
\text { hanya sebatas pada studi } \\
\text { tentang peraturan tetapt } \\
\text { keluar dan melihat efek dari } \\
\text { hukum dan bekerjanya } \\
\text { hukum; progresif memiliki } \\
\text { Hukum prom teori } \\
\text { kedekatan dengan }\end{array}$ \\
\hline
\end{tabular}

\begin{tabular}{|l|l|}
\hline & $\begin{array}{l}\text { hukum alam, karena peduli } \\
\text { terhadap hal-hal yang "meta } \\
\text { juridical" }\end{array}$ \\
6. & $\begin{array}{l}\text { Hukum progresif memiliki } \\
\text { kedekatan dengan critil } \\
\text { legal studies namun } \\
\text { cakupannya lebih luas. }\end{array}$ \\
\hline
\end{tabular}

Adapun Romli Atmasasmita menyimpulan terdapat 9 (sembilan) pokok pikiran Teori Hukum Progresif yang disampaikan oleh Satjipto Rahardjo yang berintikan sebagai berikut :

1. Hukum menolak tradisi analytical jurisprudence atau rechtsdogmatiek dan berbagi paham dengan aliran seperti legal relism, freirechtslehre, sociological jurisprudence, interressenjurisprudenz $\mathrm{di}$ Jerman, teori hukum alam dan critical legal studies.

2. Hukum menolak pendapat bahwa ketertiban (order) hanya bekerja melalui institusi-institusi kenegaraan.

3. Hukum Progresif ditujukan untuk melindungi rakyat menuju kepada ideal hukum.

4. Hukum menolak status-quo serta tidak ingin menjadikan hukum sebgai teknologi yang tidak bernurani, melainkan suatu institusi yang bermoral.

5. Hukum adalah suatu institusi yang bertujuan mengantarkan manusia kepada kehidupan yang adil, sejahtera dan membuat manusia bahagia.

6. Hukum progresif adalah, "hukum yang pro rakyat" dan "hukum yang pro keadilan".

7. Asumsi dasar hukum progresif adalah bahwa "hukum adalah untuk manusia", bukan sebaliknya. Berkaitan dengan hal tersebut, mka hukum tidak ada untuk dirinya sendiri, melainkan untuk sesuatu yang lebih luas dan lebih besar. maka setiap kali ada maslah dalam dan dengan hukum, 
hukumlah yang ditinjau dan diperbaiki, bukan manusia yang dipaksakan untuk dimasukkan ke dalam sistem hukum.

8. Hukum bukan merupakan suatu institusi yang absolut dan final melainkan sangat bergantung pada bagaimana manusia melihat dan menggunakannya. Manusialah yang merupakan penentu.

9. Hukum selalu berada dalam proses untuk terus menjadi (law as proses, law in the making). ${ }^{25}$

Beberapa ulasan di atas menunjukkan bahwa penelaahan terhadap Teori Hukum Progresif bukanlah pekerjaan yang sederhana. Sejak gagasan ini digulirkan di kalangan akademisi membawa arus yang sedikit banyak melawan arus penegakan hukum di tanah air yang cenderung dinilai sangat formalistik dan legalistik. Upaya menerjemahkan gagasan tersebut dalam ranah hukum yang lebih teknis menuntut perubahan di tataran filofis kalau tidak dikatakan bersifat mendasar. Upaya merubah pola pikir dan budaya hukum yang berkembang saat ini yang tersistematisasi dalam substansi dan struktur hukum membutuhkan waktu yang cukup lama.

Sejak bergulirnya gagasan Teori Hukum Progresif ini menimbulkan banyak kajian dan penafsiran sampai pada pandangan-pandangan yang mengkritisi THP tersebut. ${ }^{26}$ Memahami bahkan menerjemahkan THP ke dalam ranah hukum masing-masing ilmuwan bahkan praktisi hukum bukanlah pekerjaan yang sederhana dan mudah. Sebagian pemerhati yang berkecimpung dalam THP menangkap essensi progresivitas yang terdapat dalam THP itulah sesungguhnya yang menjadikan THP ini bergulir dan menjadi "living law" di dalam sanubari dan "spritulitas" bagi ilmuwan atau pegiat hukum yang selanjutnya diterjemahkan ke dalam ranah-ranah profesionalitas mereka baik secara evolusioner maupun revolusioner. Nilai progresivitas tersebut menjadi nilai tambah yang mengilhami dan memberikan jalan bagi kemana arah supremasi hukum itu ingin ditegakkan. Sehingga nilai keadilan substantiflah yang dikedepankan dalam progresivitas THP tersebut.

Dengan demikian THP sesungguhnya ingin mengajarkan pada teoritisi maupun praktisi hukum di Indonesia untuk melakukan pembebasan yang menurut Satjipto Rahardjo bermuara pada dua hal yaitu : (a) pembebasan terhadap tipe, cara berfikir, asas dan teori yang selama ini dipakai (b) pembebasan terhadap kultur penegakan hukum (administration of justice) yang selama ini berkuasa dan dirasa menghambat usaha hukum untuk menyelesaikan persoalan. Pembebasan ini dilatarbelakangi oleh ketidakpuasan atas kualitas cara berhukum kita yang menafikan nilai keadilan substantif. Keadilan substantif adalah keadilan sesungguhnya yang bersumber dari mata hati masyarakat, yang melihat jauh ke depan bagaimana keadilan itu sesungguhnya ditegakkan. Cara berhukum kita yang menghasilkan pola penegakan hukum yang sangat jauh dari keadilan substantif inilah yang mendasari juga muncul dan berkembangnya pemikiran THP tersebut. Oleh karena nilai progresivitas dalam THP ini memasuki ranah-ranah yang lebih "moral dan spiritual" sifatnya, maka sebagai sebuah gagasan THP tetap hidup dan bersinergi dengan perjalanan cara berhukum bangsa ini di masa-masa yang akan datang.

Dalam salah satu tulisan penutup tentang THP, Satjipto Rahardjo mengungkapkan sebagai berikut :

Hukum Progresif dan Ilmu Hukum Pogresif barangkali tidak bisa disebut sebagai suatu tipe hukum yang khas dan selesai (distict type and a finite scheme), melainkan lebih merupakan gagasan yang 
mengalir, yang tidak mau terjebak ke dalam status quo, sehingga menjadi mandek (stagnant). Hukum progresif selalu ingin setia pada asas besar, 'hukum adalah untuk manusia'. Hukum progresif bisa diibaratkan sebagai papan petunjuk yang selalu memperingatkan, hukum itu harus terus menerus merobohkan, mengganti, membebaskan hukum yang mandek, karena tidak mampu melayani lingkungan yang berubah..... $^{27}$

Dari uraian tersebut maka dapatlah kita fahami bahwa upaya Satjipto Rahardjo dalam mengulirkan gagasan hukum progresif dalam merespon penegakan hukum memunculkan banyak tanggapan. Sebagai sebuah gagasan ilmiah yang digulirkan tentunya di masa yang akan datang di uji oleh zaman. Menjadi ilmu yang selalu berubah tentu mengandung risiko sendiri. Risiko yang harus ditanggung oleh ilmu hukum hukum progresif adalah "penyebutannya sebagai ilmu yang tidak jelas", "bukan ilmu yang konkret" dan penamaan lain yang serupa. Di tengah-tengah konvensi (state of the art) dunia ilmu yang menuntut agar sekalian ilmu menjadi disiplin yang jelas, maka ilmu hukum progresif bisa menjadi anomali. Itulah resiko suatu tipe ilmu yang konsisten dengan pencarian terhadap kebenaran. ${ }^{28}$

\section{Kajian Kritis Teori Hukum Progresif terhadap Putusan Mahkamah Konstitusi No : 46/PUU- VII/2010}

Putusan Mahkamah Konstitusi No: 46/PUU-VII/2010 secara konstitusional memberikan pengaruh yang sangat signifikan terhadap regulasi perkawinan Indonesia khususnya keberadaan hukum positif : UU No. 1 Tahun 1974. Kekakuan peraturan maupun banyaknya kasus yang terjadi di masyarakat mendapat perhatian yang khusus utamanya perlindungan hukum bagi hakhak keperdataan anak luar nikah dari bapak biologisnya.

Sepanjang perjalanan sejarah regulasi perkawinan di Indonesia dalam memberikan perlindungan hukum khususnya hak-hak keperdataan bagi anak adalah yang di lahirkan dari perkawinan yang sah. Sah secara agama dan sah secara Negara artinya terdapat administrasi pencatatannya. Oleh karena perlindungan anak yang sah dimulai dari perkawinan yang sah, maka logika hukum bisa sebaliknya yaitu anak yang tidak sah atau anak di luar perkawinan yang tidak sah. Anak yang dilahirkan dari perkawinan yang tidak sah sangatlah beragam, bisa anak perkawinan siri, anak hasil perselingkuhan/perzinaan, anak yang dilahirkan tanpa ikatan perkawinan (semen leven), anak sumbang (incest) yang kehadirannya tidak didahului dengan perkawinan yang disahkan dan diadministrasikan. Oleh karena anak yang dilahirkan oleh orangtuanya membawa konsekuensi hukum dan sosial maka perlindungannya secara HAM adalah mutlak bagi mereka.

Selama ini hukum positif belum memberikan sanksi perdata apalagi sanksi pidana dalam peraturan perundangundangan bagi orang tua yang melahirkan anak di luar perkawinan yang sah dengan melepaskan tanggungjawabnya. Sifat sanksi yang ada hanya sanksi sosial dari masyarakat maupun sanksi agama di hari kemudian. Padahal keberadaan anak yang dilahirkan dalam alam dunia menuntut banyak konsekuensi HAM karena secara hukum perdata statusnya sebagai subjek hukum. Perlindungan hukum positif keperdataan bagi anak di luar nikah yang diakui hanya mempunyai hubungan keperdataan dengan ibu dan keluarga ibunya.

Oleh karena efek sosial pada anak yang dilahirkan di luar perkawinan yang sah mempengaruhi aspek jiwa dan tumbuh kembang fisik anak tersebut maka perlakuan diskriminasi tidak bisa 
dihindari. Pemenuhan hak-hak anak dari segi nafkah, pemeliharaan dan perawatan, jaminan pendidikan dan kesehatan, hak waris sampai perhatian dan kasih sayang menjadi persoalan prinsip dalam hidup. Hal ini sesuai dengan amanah UU No.23 Tahun 2002 tentang Perlindungan Anak. Inilah kajian awal THP yang menyatakan hukum itu untuk manusia bukan manusia untuk hukum, artinya meminimalisir perlakukan diskriminatif tersebut dapat dilakukan dengan cara merubah ketentuan hukum positif tentang status anak di luar nikah dengan tanggungjawab hukum dibebankan juga pada suami atau bapak biologisnya termasuk keluarga bapak biologisnya. Kecanggihan IPTEKS saat ini dapat dimanfaatkan sebagi salah satu alat bukti pendukung dalam hukum beracara di peradilan dan hal ini bukanlah sesutau yang asing di era modern seperti sekarang ini.

Perubahan secara mendasar dapat ditelaah dari pertimbangan Majelis Hakim yang memutuskan : Pasal 43 ayat (1) UU Perkawinan yang menyatakan, "Anak yang dilahirkan di luar perkawinan hanya mempunyai hubungan perdata dengan ibunya dan keluarga ibunya", bertentangan dengan UUD 1945 sepanjang dimaknai menghilangkan hubungan perdata dengan laki-laki yang dapat dibuktikan berdasarkan ilmu pengetahuan dan teknologi dan/atau alat bukti lain menurut hukum ternyata mempunyai hubungan darah sebagai ayahnya, sehingga ayat tersebut harus dibaca, "Anak yang dilahirkan di luar perkawinan mempunyai hubungan perdata dengan ibunya serta dengan lakilaki sebagai ayahnya yang dapat dibuktikan berdasarkan ilmu pengetahuan dan teknologi dan/atau alat bukti lain menurut hukum mempunyai hubungan darah termasuk hubungan perdata dengan keluarga ayahnya"

Inilah makna hukum untuk manusia dalam THP yang dalam proses pemaknaannya merespon keinginan publik yang lebih memihak ke rakyat (para pencari keadilan) dan menegakkan keadilan subtantif. Olah pikir dan perilaku hukum yang secara normatif terhadap status anak di luar perkawinan yang bersifat satus quo diterobos dengan kepekaan hakim dalam membebaskan olah pikir dan perilaku hukum yang selama ini berjalan. Pengakuan bapak biologis melalui ipteks dan alat bukti lain 29 menandaskan bahwa Majelis Hakim yang sangat menentukan dan tidak meninggalkan kenormatifan dalam berhukum. Esensi pembuktian di sidang pengadilan menjadikan alat bukti tersebut menegaskan kembali bahwa tidak ada yang dilanggar dalam kode etik profesi hukum. Sehingga tujuan putusan tersebut dalam kacamata THP sangat melindungi rakyat utamanya anak di luar nikah agar mereka juga bisa berkehidupan yang adil serta membuat sejahtera dan bahagia. Dengan demikian putusan Majelis Hakim MK ini merupakan upaya penemuan hukum untuk mengisi kekosongan hukum dalam upaya melindungi hak keperdataan anak luar nikah.

Putusan MK terhadap kasus anak luar nikah ini merupakan satu dari sekian banyak kasus anak yang dilahirkan dari perkawinan yang illegal, dengan kata lain kasus yang diputuskan MK adalah salah satu pucuk gunung es yang terpendam. Para pencari keadilan selalu berupaya menempuh jalur hukum agar bapak biologis dan keluarganya dapat mengakui sehingga masa depan anak tersebut dapat terjamin, yang selama ini dibebankan tanggungjawabnya pada ibu dan keluarganya. Responsifitas Hakim MK tersebut merupakan bentuk kepedulian terhadap perlindungan hak-hak keperdataan bagi anak luar nikah.Putusan MK tersebut juga membuktikan bahwa UU maupun Lembaga Hukum bukanlah institusi yang final dan mutlak, tetapi selalu dalam proses menjadi (law as a process) yang lebih baik lagi sesuai dengan aspirasi masyarakat. 
Di satu sisi putusan MK tidak saja memberikan nilai kesejahteraan dan kebahagaiaan utamanya bagi anak yang dilahirkan di luar perkawinan tetapi juga mengakomodir keinginan publik utamanya ibu yang melahirkan anak di luar perkawinan yang selama ini belum mendapatkan perlindungan hak-hak keperdatannya.Dalam kajian ini perlu dipertegas bahwa status hukum anak luar nikah hanya diperuntukkan bagi anak yang di lahirkan dari perkawinan sirri atau sering disebut dengan perkawinan di bawah tangan (yang sah menurut Syari'ah) sesuai dengan kronologis yang diajukan oleh pemohon. Sedangkan anak yang dilahirkan dari hasil perselingkuhan/perzinahan, hidup bersama tanpa ikatan perkawinan (semen leven) maupun hubungan sedarah (incest/sumbang) tidak dapat diakui. ${ }^{30}$ Ketegasan MK dalam hal ini diperlukan pula agar supaya jaminan perlindungan hak-hak keperdataan juga ditujukan pada anak hasil perselingkuhan/perzinahan maupun hubungan sedarah (incest/sumbang).

Putusan MK merupakan bentuk dari implementasi kecerdasan moral dan spiritual yang membangun nilai-nilai keadilan dan dikemas dalam putusan yuridis. Kecerdasan moral dan spiritual tidak dibatasi pedoman, tidak dibatasi oleh tekstual tetapi ingin keluar dari situasi yang ada yang selama ini menjadi peristiwa umum di masyarakat untuk diangkat menjadi persoalan yang dapat dicarikan solusi berdasarkan nilai kebenaran yang dirasakan bagi semua orang. Masa transisi yang dimulai dari proses memformulasikan putusan sampai ke putusan final adalah suatu perilaku yang dipengaruhi oleh budaya hukum Hakim bersangkutan. Pola pikir, akhlak dan perilaku Hakim yang memutuskan suatu perkara sangat besar pengaruhnya pada kualitas putusan yang dibuat sehingga nantinya berdampak sebagai institusi hukum yang bermoral. Hal ini mengindikasikan bahwa, apa dan bagaimana hukum sangat tergantung pada manusia. Manusialah yang merupakan penentu. Artinya akal pikiran manusia yang menafsirkan hukum atas realitas sosial bukanlah satu-satunya instrumen yang sangat menentukan, melainkan intuisi nurani manusia yang bersangkutan juga menentukan.

Putusan MK telah mengganti dan menerobos paradigma bekerjanya hukum sesuai peraturan menuju ke paradigma perilaku manusia, yaitu melihat tujuan sosial yang ingin dicapai dari bekerjanya hukum. 31 Pandangan hakim dalam memutuskan perkara yang mengkaji dan mempertimbangkan permohonan untuk melakukan judicial review terhadap Pasal 43 ayat (1) Undang-Undang Perkawinan adalah bertentangan dengan UUD'45 secara bersyarat (conditionally unconstitutional). Dikatakan inkonstitusional sepanjang ayat tersebut dimaknai menghilangkan hubungan perdata dengan laki-laki yang dapat dibuktikan berdasarkan ilmu pengetahuan dan teknologi dan/atau alat bukti lain menurut hukum mempunyai hubungan darah sebagai ayahnya. Tujuan sosial yang ingin dicapai adalah anak di luar nikah diberikan perlindungan hukum pada hak-hak keperdataannya dengan pembuktian bapak biologisnya. Hal ini menandaskan bahwa setiap kali ada masalah dalam dan dengan hukum, hukumlah yang ditinjau dan diperbaiki, bukan manusia yang dipaksakan untuk dimasukkan ke dalam sistem hukum.

Mencermati putusan MK tersebut tentunya tidak begitu saja diterima semua pihak. Dalam kacamata ilmuwan hukum, pertimbangan hukum atas putusan tersebut sangat memberikan angin segar bagi kajian hukum di tanah air. Sebagai suatu putusan fenomenal dan kontroversial yang ke depan diarahkan pada yurisprudensial dalam putusan hakim tentunya hal ini menjadi batu uji bagi jajaran hakim-hakim yang ada di Indonesia, apakah putusan ini bisa diikuti pada kasus yang sama atau mereka 
mempunyai pandangan atau penafsiran baru yang berbeda dengan putusan MK tersebut. Oleh karena perkara perkawinan merupakan ranah hukum perdata yang sangat pribadi sifatnya maka seringkali persoalan agama yang masuk ke ranah hukum Negara menimbulkan persoalan yang pelik dan bahkan sangat memungkinkan bernuansa SARA. Inilah sesungguhnya yang menjadi fokus dalam kajian ilmu hukum utamanya inovasi dan kreatifitas hakim dalam menemukan hukum untuk mengisi kekosongan hukum bukanlah pekerjaan mudah. Pemaknaan hukum progresif dalam hal ini bahwa manusia berada di atas hukum, bukan sebaliknya. Hukum adalah sarana untuk memudahkan segala kebutuhan hidup manusia.

Dengan demikian hukum progresif sangat bertumpu pada manusia yang menjalankan penegakan hukum sehingga aspek inovasi dan kreatifitas menjadi kata kunci dalam mengatasi kekosongan hukum dengan melakukan terobosanterobosan hukum bila perlu melakukan rule breaking . ${ }^{32}$ Bagi hukum progresif, proses perubahan tidak lagi berpusat pada peraturan, tapi pada kreatifitas pelaku hukum mengaktualisasikan hukum dalam ruang dan waktu yang tepat. Para pelaku hukum progresif dapat melakukan perubahan dengan melakukan pemaknaan yang kreatif terhadap peraturan yang ada, tanpa harus menunggu perubahan peraturan (changing of law). Peraturan yang buruk tidak harus menjadi penghalang bagi para pelaku hukum progresif untuk menghadirkan keadilan untuk rakyat dan pencari keadilan, karena mereka dapat melakukan interpretasi secara baru setiap kali terhadap suatu peraturan. 33

Di satu sisi sandaran hukum positif harus jelas untuk menjamin kepastian hukum, ${ }^{34}$ di sisi lain adalah kemampuan membaca mata hati masyarakat merupakan problematika keadilan yang harus dapat ditangkap sedini dan seawal mungkin sejak perkara tersebut diperiksa sampai diputuskan. Dalam perkembangan kasus hukum di tanah air, hakim selalu saja dihadapkan berbagai permasalahan yang membutuhkan solusi secara teknis dalam memberikan keadilan bagi para pihak yang berperkara. Pengadilan yang didalamnya terdapat aparat penegak hukum seperti hakim mempunyai kewajiban asasi untuk memberikan rasa adil tidak saja para pihak yang berperkara tetapi juga masyarakat umum. Cara pandang ini sesungguhnya merupakan bagian yang sangat essensial apa yang disebut dengan keadilan substantif dalam kajian filsafat hukum. ${ }^{35}$ Menangkap nilai keadilan substantif inilah yang menjadi tolok ukur keberhasilan putusan hakim yang menjamin putusan itu adil tidak saja dalam pandangan hukum positif saja tetapi juga dalam pandangan mata hati masyarakat. Tidak banyak hakim-hakim di Indonesia yang dengan kebebasan dan keberaniannya mampu menerapkan dua hal tersebut, sedikit diantaranya sebutlah Hakim Agung Bismar Siregar. ${ }^{36}$

Berbagai keputusan lembaga peradilan di tanah air mempunyai pengaruh yang luar biasa utamanya yang sering disebut dengan keputusan yang kontroversial atau keputusan yang fenomenal, yang menurut pandangan umum putusan tersebut merupakan terobosan hukum. Pengaruh putusan tersebut tidak saja menjadi berkualitas yurisprudensial bagi hakim lain tetapi lebih jauh lagi pada generasi mendatang yang menggunakan putusan tersebut sebagai lahan kajian bagi pendidikan hukum di tanah air. Namun hal ini pun tidak mudah karena putusan $\mathrm{MK}$ ini membawa konsekuensi logis terjadinya pro dan kontra di tanah air. Mulai yang menilai putusan ini adil sampai pada putusan ini bertentangan dengan Syari'at Islam dengan dikeluarkannya Fatwa MUI. ${ }^{37}$

Memang disadari sepenuhnya bahwa jumlah putusan yang kita sebut berkualitas tersebut tidak begitu banyak jumlahnya. Tidak begitu signifikan 
dengan kuantitas perkara yang diputuskan dari sisi kualitasnya. Hal ini ditandai dengan jumlah putusan yang berkualitas sangat dinantikan terutama bagi kalangan akademisi yang setiap hari bergelut dibidang kajian hukum maupun para pekerja hukum yang sehari-hari bergelut dengan masalah-masalah hukum. Upaya kearah pembaharuan hukum yang secara dogmatik membelenggu, dikaji dari optik sosiologis memberikan nuansa yang berbeda atas jenis putusan. Perkara yang diperiksa sampai diputuskan merupakan gambaran social reality masyarakat yang beraneka ragam cara pandang termasuk didalamnya pola penyelesaian kasus hukum.

Memadukan aliran positifistik dan aliran sosiologis bukanlah pekerjaan yang mudah bagi seorang hakim. ${ }^{38}$ Lingkungan kerja yang menutut birokrasi hukum, yang bekerja sehari-hari dalam koridor hukum formalistik dan dibahasakan sebagai prosedur hukum, mekanisme hukum. Demikian pula manajemen hukum yang ada di Mahkamah Konstitusi. Secara prosedural hukum, nilai-nilai yang dikembangkan di satu sisi mempertahankan aliran positifistik namun dalam hati sanubari hakim tidak boleh terkontaminasi di luar nilai nilai keadilan dalam memutuskan perkara yang ditanganinya. Sesunguhnya parameter untuk menilai kinerja hakim bukan saja seberapa bisa menyelesaikan tumpukan perkara setiap bulan dan setiap tahunnya tetapi bagaimana kualitas putusan terhadap perkara yang ditangani, apalagi mahkamah merupakan puncak para pencari keadilan di Indonesia. Birokrasi hukum yang digeluti sehari-hari seringkali membuat para pekerja hukum melupakan nilai-nilai substansial dari hukum yaitu keadilan substantif. Betapapun keadilan yang diperjuangkan hakim, jika masih dengan kacamata positifistik mesti berdampak pada ketidakpuasan para pihak utamanya mereka yang merasa dirugikan. Inilah sinergi yang dapat kita lihat dalam menganalisis salah satu problematika hukum yang dihadapi para hakim di Indonesia dalam memutuskan perkara yang menyita perhatian publik.

\section{Penutup}

Nilai-nilai Progresivitas dalam Teori Hukum Progresif telah diterjemahkan dalam putusan MK di atas adalah : (a) putusan MK adalah putusan hukum untuk anak di luar nikah, artinya putusan tersebut menempatkan hukum untuk manusia bukan manusia untuk hukum; (b) putusan MK telah merespon keinginan pencari keadilan yang memberikan perlindungan hak-hak keperdataan bagi anak luar nikah yaitu pengakuan dari bapak biologisnya dengan pemanfaatan ilmu pengetahuan dan teknologi dan/atau alat bukti lain menurut hukum; (c) putusan MK memberikan nilai kesejahteraan dan kebahagiaan, tidak saja bagi ibu yang melahirkan juga keluarga ibunya utamanya bagi anak yang dilahirkan di luar perkawinan yang sah; (d) putusan MK mengakomodir keinginan publik dengan melakukan rule breaking oleh hakim dalam mengaktualisasikan hukum dalam ruang dan waktu yang tepat dan melakukan pemaknaan yang kreatif terhadap peraturan yang ada, tanpa harus menunggu perubahan peraturan (changing of law). Tujuannya adalah agar hukum juga mengatur dan menjamin hak-hak keperdatan anak di luar perkawinan yang selama ini belum mendapatkan perlindungan hukum; (e) putusan MK telah mengejawantahkan sebuah putusan yang memiliki kecerdasan moral dan spiritual dengan kandungan nilai keadilan substantif yang lebih dalam.(f) putusan MK telah mengganti dan menerobos paradigma bekerjanya hukum sesuai peraturan menuju ke paradigma perilaku manusia, yaitu melihat tujuan sosial yang ingin dicapai dari bekerjanya hukum.

Putusan MK merupakan gambaran satu kasus dari sekian banyak 
kasus perkawinan yang illegal yang mengahasilkan sangat banyak jumlah anak yang dilahirkan. Mengkaji persoalan ini maka diperlukan riset yang menelusuri tentang multiplayer effect dari penelantaran $\mathrm{ibu}$ dan anak di luar perkawinan yang tidak sah. Regulasi peraturan perundang-undangan tentang perkawinan yang ada sesuungguhnya berfungsi memberikan jaminan kesetaraan dan perlindungan yang menyeluruh bagi segenap persoalan perkawinan yang ada di tanah air. Kekosongan hukum tersebut tentulah menimbulkan persoalan yang berlarutlarut, padahal fungsi pemerintah adalah memberikan kepastian dan jaminan perlindungan hukum bagi warganya. Sebutlah misalnya perkawinan campuran dan perkawinan beda agama.

Meskipun nantinya terdapat putusan Pengadilan yang menetapkan laki-laki sebagai bapak biologis dari anak luar kawin untuk melakukan tes DNA,

\section{Catatan Akhir:}

${ }^{1}$ UU No. 8 Tahun 2011 tentang Perubahan atas UU No 24 Tahun 2003 tentang Mahkamah Konstitusi, Lembaran Negara Tahun 2001 Nomor 70. Hak Konstitusional adalah hak-hak yang diatur dalam Undang-Undang Dasar Negara Republik Indonesia Tahun 1945 Pasal 28B ayat (1) yang mengatur bahwa setiap orang berhak membentuk keluarga dan melanjutkan keturunan melalui perkawinan yang sah. Dan pasal 28B ayat (2) adalah bahwa setiap anak berhak atas kelangsungan hidup, tumbuh, dan berkembang serta berhak atas perlindungan dari kekerasan dan diskriminasi. Berdasarkan kedua pasal ini, para pemohon berpendapat bahwa hak-hak konstitusionalnya adalah untuk mendapatkan pengesahan atas pernikahan dan status hukum anaknya.

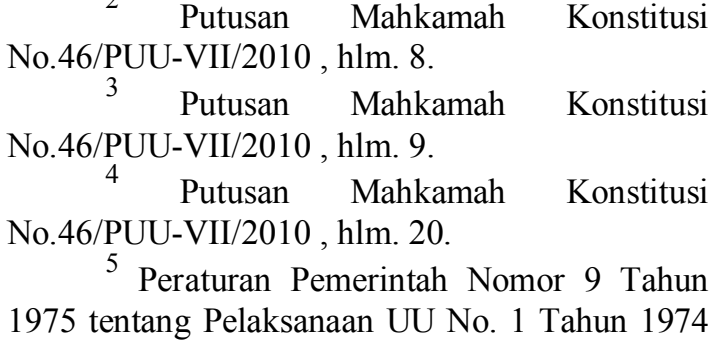

tetapi tidak ada peraturan yang mengharuskan bapak biologis untuk melakukan hal tersebut maka dapat dipastikan masalah pembuktian akan berlarut-larut bahkan mungkin tidak akan pernah terbukti. Sehingga perlu adanya peraturan teknis yang lebih jelas dan terinci mengenai kedudukan anak di luar perkawinan, khususnya masalah pengakuan dan pembuktian sebagai efek dari putusan MK tersebut.

Pemerintah diharapkan segera melakukan langkah-langkah konkret bahwa putusan MK tersebut hanya berlaku pada anak yang dilahirkan pada perkawinan siri atau perkawinan di bawah tangan yang secara Syari'ah adalah sah. Sehingga putusan MK tersebut tidak dijadikan dasar bagi pelaku perzinaan/perselingkuhan maupun semen leven untuk melakukan perlindungan hukum bagi anak yang dilahirkan.

Tentang Perkawinan. Lembaran Negara Tahun 1975 Nomor 12.

6 Putusan Mahkamah Konstitusi No.46/PUU-VII/2010, hlm. 21.

7 Putusan Mahkamah Konstitusi No.46/PUU-VII/2010, hlm. 22.

8 Putusan Mahkamah Konstitusi No.46/PUU-VII/2010, hlm. 27.

9 Bahwa perkawinan adalah sah apabila dilakukan menurut hukum masing-masing agama dan kepercayaannya itu dan tiap-tiap perkawinan dicatat menurut peraturan perundang-undangan yang berlaku. Pencatatan tiap-tiap perkawinan adalah sama halnya pencatatan peristiwaperistiwa penting dalam kehidupan seseorang misalnya kelahiran, kematian yang dinyatakan dalam-surat-surat keterangan, suatu akta yang juga dimuat dalam daftar pencatatan.

10 Putusan Mahkamah Konstitusi No.46/PUU-VII/2010, hlm. 33-34.

11 Putusan Mahkamah Konstitusi No.46/PUU-VII/2010, hlm. 34.

12 Putusan Mahkamah Konstitusi No.46/PUU-VII/2010, hlm. 34.

13 Putusan Mahkamah Konstitusi

No.46/PUU-VII/2010, hlm. 34

14 Putusan Mahkamah Konstitusi

No.46/PUU-VII/2010, hlm. 35. 
15 No.46/PUU-VII/2010, hlm. 36

16 Pendapat para hakim yang setuju dengan putusan tetapi berbeda argumentasi yang mendasari putusan disebut pendapat yang concurring. Lihat dalam Tata Wiyata dan Herry Firmansyah, Perbedaan Pendapat dalam Putusan Pengadilan (Yogyakarta: Pustaka Yustisia, 2011) dan Peter Mahmud Marzuki, Penelitian Hukum Edisi Revisi (Jakarta: Prenada Media Grup, 2013), hlm. 88.

17 Lihat dalam Putusan Mahkamah Konstitusi No.46/PUU-VII/2010, hlm. 43-44. Lebih lanjut lagi pendapat yang dikemukakan oleh Hakim Konstitusi Maria, bahwa keberadaan Pasal 2 ayat (2) UU Perkawinan menutup kemungkinan bagi anak yang lahir diluar perkawinan untuk mempunyai hubungan keperdataan dengan ayah biologisnya. Hal tersebut adalah resiko dari perkawinan yang tidak dicatatkan,tapi tidaklah pada tempatnya jika anak harus ikut menanggung kerugian yang diakibatkan oleh perbuatan kedua orang tuanya. Dengan kata lain, potensi kerugian akibat perkawinan yang tidak dicatatkan merupakan resiko bagi laki-laki dan wanita yang melakukan perkawinan, tetapi bukan resiko yang harus ditanggung oleh anak karena dalam sistem hukum Negara maupun agama tidak dikenal adanya "dosa turunan". Sehingga menurut beliau, "...pemenuhan hak-hak anak yang terlahir dari suatu perkawinan, terlepas dari sah atau tidaknya perkawinan tersebut menurut hukum Negara, tetap menjadi kewajiban kedua orang tua kandung atau kedua orang tua biologisnya". Berkenaan dengan isi putusan di atas maka Mahkamah Konstitusi selanjutnya mengeluarkan berita pers sebagai bahan penjelasan kepada masyarakat yang berjudul "Rasionalitas Putusan Nomor: 46/PUU/VIII/2010 Tanggal 17 Februari 2012 tentang Anak Yang Lahir di Luar Perkawinan (Hasil Rapat Permusyawaratan Hakim pada Senin 13 Februari 2012)". Mahkamah memberikan beberapa penegasan dan penjelasan terkait tiga hal: pertama adalah mengenai perspektif alamiah dan konstitusionalitas putusan MK dimaksud. Kedua adalah makna hukum (legal meaning) putusan MK. Ketiga adalah penjelasan dari perspektif UU Perkawinan. Lihat dalam "Rasionalitas Putusan MK Nomor: 46/PUU/VIII/2010 Tanggal 17 Februari 2012 tentang Anak Yang Lahir di Luar Perkawinan (Hasil Rapat Permusyawaratan Hakim pada Senin 13 Februari 2012)".

${ }^{18}$ Analisis terhadap putusan MK tersebut juga ditelaah oleh Taufiqurrahman Syahuri, Legislasi Hukum Perkawinan di Indonesia. Pro Kontra Pembentukannya Hingga Putusan
Mahkamah Konstutusi (Jakarta: Kencana Prenada Media Group, 2013) serta D.Y .Witanto, Hukum Keluarga: Hak dan Kedudukan Anak Luar Kawin Pasca Keluarnya Putusan MK tentang Uji Materiil UU Perkawinan (Jakarta : Pustakaraya, 2012).

${ }^{19}$ Untuk memahami THP dapat dikaji beberapa buku dan artikel jurnal yang ditulis oleh Satjipto Rahardjo diantaranya: Membedah Hukum Progresif (Jakarta: Kompas, 2006) ; Hukum dalam Jagat Ketertiban (Jakarta: UKI Press, 2006); Biarkan Hukum Mengalir (Jakarta: Kompas, 2007); Hukum dan Perilaku (Jakarta: Kompas, 2009); Hukum Progresif: Sebuah Sintesa Hukum Indonesia (Yogyakarta: Genta Publishing, 2009); Penegakan Hukum Progresif (Jakarta: Kompas, 2010); "Hukum Progresif: Hukum yang Membebaskan”, Jurnal Hukum Progresif, Vol. I. No.1/April 2005, Program Doktor Ilmu Hukum Undip Semarang.

20 Ide dasar atau gagasan orisinil Teori Hukum Progresif (THP) muncul kepermukaan dalam berbagai tulisan lepas Satjipto Rahardjo ( selanjutnya disingkat SR) di Koran Kompas sejak tahun 2002. Dimulai tulisan di Kompas 15 Juli 2002 yang berjudul Indonesia Inginkan Penegakan Hukum Progresif yang penulis kutip sebagai berikut : Indonesia tidak bisa lebih lama berlarut larut dalam cara penegakan hukum, sebagimana selama ini dijalankan. Indonesia kini membutuhkan suatu tipe penegakan hukum yang ingin disebut progresif (Penegakan Hukum progresif.PHP) Pengamatan selama ini menunjukkan, miski bangsa ini meneriakkan supremasi hukum dengan keras, hasilnya tetap mengecewakan. Untuk menagani masalah korupsi, misalnya hamper tak ada hasil yang ditunjukkan. Kata orang banyak korupsi terjadi, tetapi para koruptor dan armada hukumnya lebih pintar mematahkan jurus-jurus hukum yang ingin dikenakan kepada mereka. .....PHP adalah suatu pekerjaan dengan banyak dimensi, anatara lain : Pertama, dimensi dan factor manusia pelaku dalam PHP. Kedua, kebutuhan akan semacam kebangunan di kalangan akademisi, intektual dan ilmuwan serta teoritisi hukum Indonesia.Selama lebih kurang seratus tahun mereka telah menjadi murid yang baik dari filsafat hukum liberal.Kini mereka ditantang oleh kebutuhan dan penderitaan bangsanya untuk berani membebaskan diri dari ajaran dan doktrin yang selama ini dijalankan. Walaupun SR sendiri belum menyebutkan spesifik Teori Hukum Progresif namun menjadi wacana yang menggelinding dan membentuk opini masyarakat akademik terutama yang berkecimpung di bidang sosiologi hukum sampai dibentuk Satjipto Rahardjo Institute setelah kepulangan beliau keharibaan Ilahi. Tentang Perjalanan Teori 
Hukum Progresif dapat ditelaah tulisan yang dibuat oleh Mahmud Kusuma, Menyelami Semangat Hukum Progresif: Terapi Paradigmatik Bagi Lemahnya Hukum Indonesia (Yogyakarta: Penerbit Antonylib dan LSHP Indonesia, 2009); Anthon F.Susanto, "Satjipto Rahardjo Dari DNA Hukum Progresif Menuju Ruang Ontologism yang Reduksionis" dalam Satjipto Rahardjo dan Hukum Progresif Urgensi dan Kritik (Jakarta: Penerbit Epistema Institute dan Huma, 2011), hlm. 110. Lihat dalam.Satjipto Rahardjo dalam "Hukum Progresif sebagai Dasar Pembangunan Ilmu Hukum Indonesia" dimuat dalam buku Menggagas Hukum Progresif Indonesia, Penyunting Ahmad Gunawan dan Mu'amar Ramadhan, (Yogyakarta: Pustaka Pelajar, 2006). Beberapa tulisan memang belum ada kesepakatan tentang penamaan hukum progresif. Ada yang menggunakan teori, ilmu dan ada yang hukum saja, hal ini tentunya tergantung dari teks yang dimaksud oleh penulis masing-masing diarahkan kemana maksud dan tujuan penulisannya. Menurut Otje Salman dan Anthon F.Susanto, pemikiran Satjipto Rahardjo tentang Hukum Progresif mengarah pada pembentukan teori hukum. Lihat dalam Otje Salman dan Anthon F.Susanto, Teori Hukum (Mengingat, Mengumpulkan dan Membuka Kembali) (Bandung: Refika Aditama, 2005), hlm .139.

${ }^{21}$ Lihat dalam Romli Atmasasmita, Teori

Hukum Integratif : Rekonstruksi terhadap Teori Hukum Pembangunan dan Teori Hukum Progresif (Yogyakarta: Genta Publishing, 2012), hlm. 86-87.

${ }^{22}$ Khuzaifah Dimyati, menempatkan Satjipto Rahardjo sebagai tokoh yang mengembangkan pemikiran di Indonesia Periode Ketiga, pada dekade 1970-1990 bersama Mochtar Kusumaatmaja, Sunaryati Hartono dan Mohammad Koesnoe. Tipologi pemikiran hukum pada periode ini dapat dipandang sebagai pemikiran yang bersifat transformatif. Artinya, pemikir transformatif bukan hanya menyentuh aspek-aspek normatif dan doktrinal semata-mata, melainkan berusaha menstransformasikan fenomena-fenomena hukum dari arah empiris yang dikonstruksikan ke dalam tataran teoritik filosofis. Lihat Khuzaifah Dimyati, Teorisasi Hukum: Studi tentang Perkembangan Pemikiran Hukum di Indonesia 1945 - 1990 (Yogyakarta: Genta Publishing, 2010), hlm. 235-237. Sedangkan Bernard L.Tanya menempatkan Satjipto Rahardjo masuk dalam pencetus Teori Hukum di Masa Transisi. Lihat dalam Bernard L.Tanya dkk., Teori Hukum: Strategi Tertib Manusia Lintas Ruang dan Generasi (Yogyakarta: Genta Publishing, 2010), hlm. 204212.
23 Tulisan Shidarta dalam "Posisi pemikiran hukum progresif dalam konfigurasi aliran-aliran filsafat hukum : Sebuah diagnosis awal" dimuat dalam Satjipto Rahardjo dan Hukum Progresif, hlm. 55-58.

24 Tulisan Yudi Kristiana dalam "Menanti Progresivitas Kejaksaan" dimuat dalam Satjipto Rahardjo dan Hukum Progresif, hlm. 237-238. Identifikasi THP ini merupakan hasil riset Disertasi Yudi Kristiana di PDIH UNDIP Semarang dengan judul : "Rekonstruksi Birokrasi Kejaksaan dengan Pendekatan Hukum Progresif: Studi Penyelidikan, Penyidikan dan Penuntutan Tindak Pidana Korupsi”, tahun 2007.

25 Romli Atmasasmita, Teori Hukum Integratif, hlm. 88.

26 Bernard.L.Tanya menyatakan bahwa pembaharuan yang ditawarkan oleh hukum progresif membutuhkan sebuah model atau kerangka kerja yang dapat memandu mereka dalam menjalankan hukum progresif tersebut. Tanpa panduan atau model yang jelas yang berfungsi sebagai platform, sulit kekuatan hukum progresif disatukan dalam satu komitmen. Bernard L. Tanya mengajukan 3 pertimbangan dan 3 perangkat lunak untuk mendukung THP tersebut. Lihat dalam Bernard L. Tanya, Hukum, Politik dan KKN (Surabaya: Srikandi, 2005), hlm. 6-8.

27 Satjipto Rahardjo, Hukum Progresif: Sebuah Sintesa Hukum Indonesia, Genta Publishing Yogyakarta, 2009.hlm. 84-85. Secara garis besar, gagasan hukum progresif merefleksikan pertarungan keyakinan yang ada dalam diri beliau, di tengah serbuan dogmatis terhadap cara berhukum Indonesia, ditambah dengan diamnya kaum intelektual terhadap situsi ini. Karena itulah beliau menyuarakan gagasannya. Lihat dalam Anthon. F. Susanto, "Satjipto Rahardjo: Dari DNA Hukum Progresif Menuju Ruang Ontologism yang Reduksionis" dalam Satjipto Rahardjo dan Hukum Progresif., hlm. 111

28 Lihat Satjipto Rahardjo, Hukum Progresif, hlm. 2-3. Teori Hukum Progresif yang digagas oleh Satjipto Rahardjo sesungguhnya tidak hanya berlaku di Indonesia. Karena ide gagasan ini berupa teori maka sifat general dan universal dapat digunakan juga pada THP ini di negara lain. Walaupun THP ini bermula dari persoalan penegakan hukum yang khas ke Indonesiaan. Hal ini juga tidak berbeda jauh dengan Teori Hukum Pembangunan dari Mochtar Kusuma Atmadja. Ada banyak contoh pemikir hukum yang mendasarkan pandangan teoritisnya dari titik beranjak pada sistem hukum negaranya sendiri seperti : Lawrence M.Friedman, Richard A.Posner maupun Brian Tamanaha. Lihat dalam 
Shidarta (ed), Mochtar Kusuma-Atmadja dan Teori Hukum Pembangunan: Eksistensi dan Implikasi (Jakarta: Epistima Institute dan Huma, 2012), hlm. 58.

${ }^{29}$ Penjelasan adanya ilmu pengetahuan dan teknologi tidak hanya test DNA, juga alat bukti lain dalam hukum acara perdata terdapat dalam pasal 284 RBg/164 HIR/1866 KUH Perdata yaitu : bukti surat, bukti saksi, persangkaan, pengakuan dan sumpah. Sedangkan menurut Pasal 100 sampai dengan 106 dalam UU No.5 Tahun 1986 tentang Peradilan TUN : surat atau tulisan, keterangan ahli, keterangan saksi, pengakuan para pihak dan pengetahuan hakim. Dalam Hukum Acara Mahkamah Konstitusi sebagaimana disebutkan dalam UU No.8 tahun 2011 tentang Perubahan UU No. 24 tahun 2003 tentang Mahkamah Konstitusi pada Pasal 36 ayat (1) alat bukti terdiri atas : surat atau tulisan, keterangan saksi, keterangan ahli, keterangan para pihak, petunjuk dan alat bukti lain berupa informasi yang diucapkan, dikirim, diterima atau disimpan secara elektronik dengan optik atau yang serupa dengan itu.

30 Sebagai perbandingan dalam $\mathrm{KUH}$ Perdata disebutkan bahwa anak luar kawin dapat diakui jika dilakukan proses pengakuan dan pengesahan oleh bapak biologisnya. Lihat ketentuan dalam Pasal 270 sd.Pasal $289 \mathrm{KUH}$ Perdata.

31 Pendekatan positivistik yang lebih mementingkan aspek-aspek umum, fakta-fakta empirik yang merupakan bagian luar saja dari realitas sebenarnya telah membawa kekeliruan mendasar dalam memahami hukum. Dalam teori chaos/non sistematik, realitas hukum harus dipahami, dihayati dan dimakanai secara mendalam karena hanya melalui cara tersebut, realitas hukum yang sesungguhnya dapat diungkap. Lihat dalam Anthon F. Susanto, Ilmu Hukum Non Sistematik: Fondasi Filsafat Pengembangan Ilmu Hukum Indonesia (Yogyakarta: Genta Publishing, 2010), hlm. 10.

32 Rule Breaking didefinisikan sebagai suatu terobosan hukum yang bertujuan untuk mengatasi adanya kebuntuan atau kemacetan hukum dalam rangka mewujudkan tujuan ideal dan nilai-nilai hukum. Lihat dalam $\mathrm{M}$. Syamsudin, Konstruksi Baru Budaya Hukum Hakim (Jakarta: Kencana Prenada Media Group, 2012), hlm. 272. Menurut Satjipto Rahardjo, ada tiga cara untuk melakukan rule breaking, yaitu : (1) mempergunakan kecerdasan spiritual untuk membangun dari keterpurukan hukum ini memberikan pesan penting bagi kita untuk berani mencari jalan baru (rule breaking) dan tidak membiarkan diri terkekang cara lama , menjalankan hukum yang lama dan tradisional yang jelas-jelas lebih banyak melukai rasa keadilan .(2) pencarian makna lebih dalam hendaknya menjadi ukuran baru dalam menjalankan hukum dan bernegara hukum.Masing-masing pihak yang terlibat dalam proses penegakan hukum didorong untuk selalu bertanya kepada hati nurani masing-masing makan hukum yang lebih dalam. (3) hukum hendaknya dijalankan tidak menurut prinsip logika saja, tetapi dengan perasaan, kepedulian dan keterlibatan (compassion) kepada kelompok yang lemah. Lihat dalam Yusriyadi,'Paradigma Sosiologis dan Implikasinya terhadap Pengembangan Ilmu Hukum dan Penegakan Hukum di Indonesia”, Pidato Pengukuhan sebagai Guru Besar FH UNDIP, Semarang tahun 2006, hlm. 32-33.

33 Bernard L. Tanya dkk., Teori Hukum.Strategi Tertib Manusia Lintas Ruang dan Generasi (Yogyakarta: Genta Publishing, 2010), hlm. 212-213.

34 Satjipto Rahardjo tidak menampik keberadaan hukum tertulis, misalkan konstitusi tertulis. Tetapi konstitusi tertulis itu harus dibaca secara bermakna agar bisa menyelami moral yang ada di balik konstitusi tertulis. Gagasan ini merujuk kepada pemikiran Ronald Dworkin tentang the moral reading of the constitution. Lihat dalam Yance Arizona, "Negara hukum bernurani”, dalam Satjipto Rahardjo dan Hukum Progresif., hlm. 134.

35 Keadilan substantif dapat didefiniskan sebagai the truth justice (sebenar keadilan, keadilan yang sebenarnya). Pertimbangan utama pencarian keadilan substansial bukan lagi aspek formal (state law) dan materiil (living law) hukum melainkan aspek hakikat hukum, yakni dilibatkannya pertimbangan moral, ethic and religion. Werner Menski dalam Comparative Law in Global Context (2006) menyebut keadilan substantif sebagai "perfect justice". Pencarian keadilan substantif hanya dapat dicapai dengan penggunaan pendekatan legal pluralism. Lihat dalam Suteki, Desain Hukum di Ruang Sosial (Yogyakarta: Thafa Media, 2013), hlm. 217.

36 Hakim Agung Bismar Siregar (Alm) dijadikan contoh oleh Satjipto Rahardjo untuk mendiskusikan relasi pengadilan dan perilaku Hakim. Lihat dalam Satjipto Rahardjo, Sosiologi Hukum: Perkembangan, Metode dan Pilihan Masalah (Surakarta: UMM Press, 2002), hlm. 115. Perilaku Hakim Agung Bismar Siregar, dijadikan lahan riset oleh Antonius Sudirman, dengan judul Hati Nurani Hakim dan Putusannya.Suatu Pendekatan dari Perspektif Ilmu Hukum Perilaku (Behavioral Jurisprudence) Kasus Hakim Bismar Siregar (Bandung: Citra Aditya Bakti, 2007). Sebagai perbandingan kajian tentang kebebasan hakim dapat dibaca tulisan dari 
Ahmad Kamil, Filsafat Kebebasan Hakim (Jakarta: Kencana, 2012).

37 Lihat dalam Fatwa MUI Nomor : 11 Tahun 2012 tentang Kedudukan Anak Hasil Zina dan Perlakuan Terhadapnya pada tanggal 10 Maret 2012.

38 Dalam salah satu tulisannya Satjipto Rahardjo menulis pentingnya penafsiran hukum yang progresif yaitu peraturan sebagai sesuatu yang legal dan kenyataan sebagai sesuatu yang sociological, empirical, bukan dua hal yang terpisah dan bisa dipisahkan secara mutlak. Pada waktu kita berbicara mengenai penafsiran, maka keduanya akan saling memasuki. Peraturan akan melihat kepada kenyataan sedang kenyataan melihat kepada peraturan. Maka pekerjaan penafsiran menjadi bukan semata-mata membaca peraturan menggunakan logika peraturan melainkan juga membaca kenyataan atau apa yang terjadi di masyarakat. Kedua pembacaan itu disatukan dan dari situ akan muncul kreatifitas, inovasi dan progresivisme. Lihat dalam Satjipto Rahardjo, Hukum dalam Jagat Ketertiban (Jakarta: UKI Press, 2006), hlm. 170-171.

\section{DAFTAR PUSTAKA}

Alschuler, A. W. Law Without Values. Chicago: The University of Chicago Press, 2000.

Altman, Audrew. Critical Legal Studies, A Liberal Critique. Paris: Princeton University Press, 1990.

Atmasasmita, Romli. Teori Hukum Integratif: Rekonstruksi terhadap Teori Hukum Pembangunan dan Teori Hukum Progresif. Yogyakarta: Genta Publishing, 2012.

Carter, Lief. H. Reason in Law. Canadam Little, Brown \& Company, 1984.

Davitt, Thomas. E. Nilai-Nilai Dasar di Dalam Hukum. Menganalisa Implikasi-implikasi Legal-Etik Psikologi dan Antropologi bagi Lahirnya Hukum, terj. Yudi Santoso. Yogyakarta: Pallmal, 2012.

Dimyati, Khuzaifah. Teorisasi Hukum: Studi tentang Perkembangan Pemikiran Hukum di Indonesia
1945 - 1990. Yogyakarta: Genta Publishing, 2010.

Gunawan, Ahmad dan Ramadhan, Mu'ammar. Menggagas Hukum Progresif Indonesia. Yogyakarta: Pustaka Pelajar, 2006.

Hunt, Alan. The Sociological Movement in Law. The Macmillan Press LTD, 1978.

- Explorations in Law and Society. London: Routledge, 1993.

Hutchinson, Allan. C. Critical Legal Studies. USA : Rowman \& Littlefield Publishers Inc, 1989.

Kamil, Ahmad. Filsafat Kebebasan Hakim. Kencana: Jakarta, 2012.

Kusuma, Mahmud, Menyelami Semangat Hukum Progresif: Terapi Paradigmatik Bagi Lemahnya Hukum Indonesia. Yogyakarta: Penerbit Antonylib dan LSHP Indonesia, 2009.

Luhmann, Niklas. A Sociological Theory of Law. London: Routledge dan Kegan Paul, 1985.

Marwan, Awaludin. Studi Hukum Kritis, Dari Modern, Posmodern hingga Posmarxis. Yogyakarta: Satjipto Rahardjo Institute dan Thafa Media, 2012.

Marzuki, Peter Mahmud. Penelitian Hukum. Jakarta: Prenada Media Grup, 2013.

Rahardjo, Satjipto. Sosiologi Hukum: Perkembangan, Metode dan Pilihan Masalah. Surakarta: UMM Press, 2002. . "Hukum Progresif: Hukum yang Membebaskan", Jurnal Hukum Progresif, Vol. I. No. $1 /$ April 2005, Program Doktor Ilmu Hukum Undip Semarang. . Membedah Hukum Progresif. Jakarta: Kompas, 2006. Hukum dalam Jagat Ketertiban. Jakarta: UKI Press, 2006. . Biarkan Hukum Mengalir. Jakarta: Kompas, 2007. 
. Hukum dan Perilaku: Hidup

Yang Baik adalah Dasar Hukum

Yang Baik. Jakarta: Kompas. 2009.

Hukum Progresif: Sebuah Sintesa Hukum Indonesia. Yogyakarta: Genta Publishing, 2009.

. Penegakan Hukum Progresif.

Jakarta: Kompas, 2010.

Rifai, Ahmad. Penemuan Hukum oleh Hakim dalam Perspektif Hukum Progresif. Jakarta: Sinar Grafika, 2010.

Saifullah. Refleksi Sosiologi Hukum. Bandung: Refika Aditama, 2007.

Safitri, Myrna, et.al. Satjipto Rahardjo dan Hukum Progresif.Urgensi dan Kritik, Jakarta: Penerbit Epistema Institute dan Huma, 2011.

Salman, Otje dan Anthon F.Susanto. Teori Hukum (Mengingat, Mengumpulkan dan Membuka Kembali). Bandung: Refika Aditama, 2005.

Sampford, Charles. The Disorder of Law: Critical Legal Theory. New York: Basil Blackwell Inc, 1989.

Shidarta (Ed). Mochtar Kusumaatmadja dan Teori Hukum Pembangunan: Eksistensi dan Implikasi. Jakarta: Epistima Institute dan Huma, 2012.

So, Alvin.Y. Social Change and Development: Modernization, Dependency, and World System Theories. Sage Publications Inc., 1990.

Sudirman, Antonius. Hati Nurani Hakim dan Putusannya: Suatu Pendekatan dari Perspektif Ilmu Hukum Perilaku (Behavioral Jurisprudence) Kasus Hakim Bismar Siregar. Bandung: Citra Aditya Bakti, 2007.

Susanto, Anthon F. Ilmu Hukum Non Sistematik: Fondasi Filsafat Pengembangan Ilmu Hukum
Indonesia. Yogyakarta: Genta Publishing, 2010.

Dekonstruksi Hukum:

Eksplorasi Teks dan Model

Pembacaan. Yogyakarta: Genta Publishing, 2010.

Suteki. Desain Hukum di Ruang Sosial. Yogyakarta: Thafa Media, 2013.

Syahuri, Taufiqurrahman. Legislasi Hukum Perkawinan di Indonesia: Pro Kontra Pembentukannya Hingga Putusan Mahkamah Konstutusi. Jakarta: Kencana Prenada Media Group, 2013.

Syamsudin, M. Konstruksi Baru Budaya Hukum Hakim. Jakarta: Kencana Prenada Media Group, 2012.

Tanya, Bernard. L. Hukum, Politik dan KKN.Surabaya: Srikandi, 2005.

Tanya, Bernard L. dkk. Teori Hukum: Strategi Tertib Manusia Lintas Ruang dan Generasi. Yogyakarta: Genta Publishing, 2010.

Teubner, Gunther. Dilemmas of Law in the Welfare State. Berlin: Walter de Gruyter \& Co., 1985.

Unger, Roberto Mangabeira. The Critical Legal Studies Movement. Cambridge Mass: Harvard University Press, 1986.

Witanto, D.Y. Hukum Keluarga: Hak dan Kedudukan Anak Luar Kawin.Pasca Keluarnya Putusan $M K$ tentang Uji Materiil UU Perkawinan. Jakarta: Pustakaraya, 2012.

Wignjosoebroto, Soetandyo. Hukum: Paradigma, Metode dan Dinamika Masalahnya. Jakarta: Elsam dan Huma, 2002.

Wiyata, Tata dan Herry Firmansyah. Perbedaan Pendapat dalam Putusan Pengadilan. Yogyakarta: Pustaka Yustisia, 2011.

Yusriyadi. "Paradigma Sosiologis dan Implikasinya terhadap Pengembangan Ilmu Hukum dan Penegakan Hukum di Indonesia", Pidato Pengukuhan sebagai Guru 
Besar FH UNDIP, Semarang 2006.

Fatwa MUI Nomor : 11 Tahun 2012 tentang Kedudukan Anak Hasil Zina dan Perlakuan Terhadapnya pada tanggal 10 Maret 2012.

UU No. 8 Tahun 2011 tentang perubahan atas UU No 24 Tahun 2003 tentang Mahkamah Konstitusi,
Lembaran Negara Tahun 2001 Nomor 70.

Putusan Mahkamah Konstitusi

No.46/PUU-VII/2010.

Peraturan Pemerintah Nomor 9 Tahun 1975 tentang Pelaksanaan UU No. 1 Tahun 1974 Tentang Perkawinan. Lembaran Negara Tahun 1975 Nomor 12. 